BISMA - Bisnis dan Manajemen -Volume 9 No. 1 Oktober 2016

\title{
PENGARUH PENGETAHUAN PRODUK DAN PERSEPSI KUALITAS TERHADAP NIAT BELI MOBIL DATSUN GO PANCA
}

\author{
ADITYA RYAN FIRMANSYAH \\ Jurusan Manajemen, Fakultas Ekonomi, Universitas Negeri Surabaya, KampusKetintang, Surabaya 60231 \\ Email: Aditryanf@gmail.com
}

\begin{abstract}
This study aims to investigate and discuss the influence of knowledge and perception of the quality of the product purchase intentions Datsun Go Panca.

The sampling technique used is non - probability sampling and sampling conducted by judgmental sampling with a sample taken as many as 210 people. The target populationis the respondents whowere visitinga car show LCGC especially Datsun Go Panca.The scale of measurementin this study using a Likert scale. Measuring instrument usedwas a questionnaire. Analysis of data using multiple linear regression model. The results showedthat the effectof product knowledge on the intentionto buy Datsun Go Panca and influence the quality perception and purchase intent Datsun GoPanca, contributed $49.5 \%$.
\end{abstract}

Keywords: knowledge, perceived quality, and purchase intention.

\section{PENDAHULUAN}

Di era globalisasi ini, persaingan bisnis semakin ketat baik di dalam pasar Nasional maupun pasar Internasional yang menimbulkan banyaknya Produsen menawarkan produkproduk yang berkualitas agar mampu bersaing.khususnya produk-produk transportasi seperti kendaraan bermotor. Perkembangan jumlah penduduk yang sangat pesat serta beragamnya aktivitas kerja setiap orang memungkinkan segala aktivitas tersebut harus dilakukan secara cepat.

Agar orang dapat melakukan pekerjaan secara cepat, dibutuhkan sarana pendukung, seperti sarana transportasi.Transportasi merupakan alat yang berguna untuk memindahkan barang atau orang dalam kuantitas tertentu, ke suatu tempat tertentu, dalam jangka waktu tertentu (Tjiptono, 1997).Salah satu sarana transportasi tersebut adalah mobil, seperti mobil jenis city car yang banyak di minati penduduk di perkotaan besar. Karena bentuknya yang memang kecil dan juga elegan.

Pada saat ini pasar otomotif Indonesia sedang diramaikan oleh keluarnya mobil-mobil murah ramah lingkungan atau yang disebut LCGC (low cost green car). Di tahun 2013 pemerintah telah menerbitkan PP Nomor 41/2013 tentang Barang Kena Pajak Tergolong Mewah, PP tersebut menyatakan untuk mobil hemat energi dan harga terjangkau, Pajak Penjualan atas Barang Mewah atas Barang Kena Pajak sebesar 0 persen dari harga jual. Pajak 0 persen tersebut untuk motor bahan bakar cetus api dengan kapasitas silinder 1.200 cc dan konsumsi bahan bakar minyak paling sedikit 20 kilometer per liter atau bahan bakar setaranya. PP No.41/2013 telah dilengkapi dengan PermenPerindustrian No. 33/MIND/2013 tentang Pengembangan Produksi Kendaraan Bermotor Roda Empat Hemat Energi dan Harga Terjangkau pada 1 Juli 2013, (www.kemenperin.go.id).Adanya kebijakan pajak 0 persen tersebut, banyak produsen mobil yang berlomba lomba mengeluarkan produk mobil LCGC seperti Toyota Agya, Daihatsu Ayla, Karimun Wagon R, Brio Satya, dan Datsun GO Panca. Alat transportasi seperti mobil LCGC banyak di minati konsumen di kota kota besar. (www.kompas.com) .

Di Indonesia industri otomotif mobil LCGC ini menunjukkan perkembangan yang menarik.Kondisi perekonomian Indonesia yang terus membaik juga ditanggapi oleh beberapa perusahaan mobil sebagai persaingan dalam dunia bisnis untuk merebut perhatian konsumen (Suharyono, 2012).maka dari itu perusahaan harus memenuhi kebutuhan dan memperhatikan perilaku konsumen. Karena peluang pasar di Indonesia yang masih luas, banyak perusahaan mobil berusaha menciptakan produk mobil LCGC yang berkualitas.Salah satu produk yang diluncurkan di tahun ini dan menarik perhatian adalah mobil murah ramah lingkungan (Low Cost Green Car/LCGC) yang dikeluarkan Datsun, yakni Datsun Go+ Panca. (www.beritasatu.com).Datsun Go menjalin kerja sama dengan Nissan dalam memproduksi mobil LCGC, Produk terbaru dari PT Nissan Motor Indonesia (NMI), Datsun Go+ Panca memiliki spesifikasi mirip dengan mesin pacu milik Nissan March, yang mempunyai kode HR12DE. Dibekali mesin tiga silinder segaris yang mampu menghasilkan tenaga $68 \mathrm{dk}$. mesin berkapasitas 1.2 liter tersebut dipadukan dengan transmisi manual 5 percepatan.Datsun Go+ Panca mengambil basis mesin tiga silinder milik Nissan. Namun ada beberapa perubahan dilakukan guna memenuhi syarat menjadi mobil LCGC (Low Cost Green Car)., mesin yang sekarang dipakaiDatsun GO+ Panca sudah dikalibrasi ulang dibagian ECU guna konsumsi bahan bakar.

Adanya konsep low cost green car (LCGC) tersebut membuat para produsen mobil siap bersaing dipasar otomotif di Indonesia, dengan menawarkan berbagai keunggulan yang dimiliki masing-masing produk LCGCnya Namun Datsun salah satu produsen LCGC mengalami penuruan penjulan. Dari tabel di bawah ini terdapat data penjualan mobil Datsun low cost greencar (LCGC) tahun 2015, sebagai berikut: 
Aditya Ryan Firmansyah - Pengaruh Pengetahuan Produk Dan Persepsi Kualitas..

Tabe 1.Data Penjualan mobil LCGC Periode 2015

\begin{tabular}{l|c|c|c|c|c|c|c|c}
\hline & $\begin{array}{c}\text { jan } \\
2015\end{array}$ & $\begin{array}{c}\text { Feb } \\
2015\end{array}$ & $\begin{array}{c}\text { Mart } \\
2015\end{array}$ & $\begin{array}{c}\text { Aprl } \\
2015\end{array}$ & $\begin{array}{c}\text { Mei } \\
2015\end{array}$ & $\begin{array}{c}\text { Jun } \\
2015\end{array}$ & $\begin{array}{c}\text { Jul } \\
2015\end{array}$ & $\begin{array}{c}\text { Agst } \\
2015\end{array}$ \\
\hline $\begin{array}{l}\text { Datsun Go } \\
\text { Panca }\end{array}$ & 2.063 & 2.424 & 2.753 & 2.800 & 2.203 & 2.001 & 1.944 & 1.590 \\
\hline Datsun Go & 1.850 & 1.990 & 2.000 & 1.750 & 1.550 & 1.366 & 1.243 & 1.110 \\
\hline $\begin{array}{l}\text { Toyota } \\
\text { Agya }\end{array}$ & 6.552 & 7.461 & 6.648 & 6.442 & 6.721 & 6.501 & 6.552 & 7.102 \\
\hline $\begin{array}{l}\text { Daibatsu } \\
\text { Aya }\end{array}$ & 3.774 & 4.590 & 4.333 & 4.033 & 4.500 & 5.002 & 5.341 & 5.103 \\
\hline $\begin{array}{l}\text { Honda } \\
\text { Brio Satya }\end{array}$ & 2.297 & 2.061 & 1.802 & 1.224 & 2.500 & 2.986 & 3.102 & 3.314 \\
\hline $\begin{array}{l}\text { Suzuli } \\
\text { Wagon R }\end{array}$ & 1.693 & 2.158 & 2.037 & 2.172 & 2.241 & 2.401 & 2.531 & 2.412 \\
\hline
\end{tabular}

Sumber : http://oto.detik.com- Gabungan Industri Kendaraan Bermotor Indonesia (Gaikindo) dan vivaotomitf.com

Datsun Go+ Panca hadir di dalam pasar otomotif tanah air untuk menyaingi Suzuki Karimun Wagon R, Honda Brio Satya, Daihatsu Ayla dan Toyota Agya yang terlebih dahulu mendominasi di pasaran Indonesia. Datsun Go+ Panca sendiri dilepas ke pasaran dengan harga yang ditawarkan terbilang murah karena masuk dalam kategori LCGC jadi hanya berada pada kisaran 100 jutaan (www.oto.detik.com)

Di era modern ini, tingginya permintaan mobil setiap tahunya dikarenakan peningkatan pendapatan masyarakat yang terus meningkat, dan menempatkan mobil bukan lagi untuk golongan menengah keatas. Kenyataan ini didukung seperti yang diungkapkan oleh Robbi R Sukardi sebagai Ketua Umum Asosiasi Perusahaan CNG Indonesia (APCNGI), bahwa potensi kendaraan di Jawa Timur saat ini sangat besar dimana hingga akhir tahun 2013 lalu, tercatat sebanyak 1.393.471 unit kendaraan roda empat beroperasi di Jawa Timur, sekitar 586.185 unit ada di Surabaya, dari jumlah tersebut, tercatat 5.716 unit kendaraan umum dan 7.133 unit mobil dinas pemkot, serta sekitar 22 ribuan kendaraan pribadi (apcngi.org,2014).

Berdasarkan fenomena tersebut, penelitian ini bertujuan untuk menganalisis dan membahasapakah niat konsumen untukmembeli Datsun Go Panca di pengaruhi oleh pengetahuan produk dan persepsi kualitas

\section{KAJIAN PUSTAKA}

\section{Niat Beli}

Menurut Durianto (2001).menyatakan bahwa "Niat pembelian adalah sebuah kecenderungan pembelian yang timbul pada konsumen untuk melakukan pembelian pada waktu yang akan datang".Sedangkan menurut Engel et al (1995:201)mendefinisikan "niat umumnya dirujuk sebagai pembelia yang terencana sepenuhnya.Konsumen akan lebih bersedia menginvestasikan waktu dan energi dalam berbelanja dan membeli".Lebih lanjut menurut Kotler dan Keller (2009:240) menyatakan dalam tahap evaluasi, para konsumen membentuk preferensi atas merek-merek yang ada di dalam kumpulan pilihan.Konsumen juga membentuk niat untuk membeli merek yang paling disukai.

Menurut Kotler dan Keller (2008:189) untuk mengukur niat beli menggunakan dimensi antara lain sikap orang lain dan Situasi yang tidak diantisipasi. Pengukuran variabel niat beli dalam penelitian ini menggunakan indikator berdasarkan jurnal Ratna Susanti dan Dwi Hastarja (2010) yang disesuaikan dengan objek penelitian, dengan item pernyataan sebagai berikut :

a. Saya percaya produk ini benar-benar tepat untuk saya beli.

b. Saya pasti akan memilih produk LCGC Datsun Go.

\section{Pengetahuan Produk}

Menurut Sumarwan (2011:148) mendefinisikan pengetahuan produksebagai kumpulan berbagai macam informasi mengenai produk. Pengetahuan ini meliputi kategori produk, merek, terminologi produk, atribut atau fitur produk, harga produk, dan kepercayaan mengenai produk.Sedangkan menurut Peter dan Olson (2010) dalam Sumarwan (2011:148) menyebutkan bahwa konsumen memiliki tingkat pengetahuan produk yang berbeda.Lebih lanjut menurut Larkin et al (1980) dalam Roslina (2009) mengatakan bahwa pengetahuan produk konsumen di pengaruhi pemrosesan informasi. Konsumen pada umumnya akan membuat pilihan setelah mereka memperoleh informasi, meskipun informasi yang menjadi dasar pengambilan keputusan, berbeda.

Menurut Engel et al.,(1995:331) mengukur pengetahuan produk dengan tiga aspek, yaitu Subjective Knowledge, ObjectiveKnowledge, Expreince based knowledge.

Pengukuran variabelpengetahuan produk dalam penelitian menggunakan indikator menurut Engel et al (1995:331) dan dikombinasikan dengan jurnal Kambiz Heidarzadeh Hanzaee dan Khosrozadeh (2011) dan David Bamber (2011) yang disesuaikan dengan objek penelitian, dengan item pernyataan sebagai berikut :

a) Pengetahuan Objektif

1. Sayabersediamempelajarisegalahaltentangmobil Datsun Go Panca di banding mobil lcgc lainya.

2. Sayamampumembedakanproduk LCGC Datsun Go Panca denganproduk mobil LCGC lainnya

b) Pengetahuan Subjektif

1. Saya banyak mengetahui tentang mobil LCGC Datssu Go Panca.

2. Saya mampu menjelaskan keunggulan dari produk mobil Datsun Go Panca

\section{Persepsi Kualitas}

Menurut Aaker dalam Tjiptono (2005:40) menyatakan bahwa persepsi kualitas adalah penilaian konsumen terhadap keunggulan atau superioritas produk secara keseluruhan. Sementara menurut Durianto, Sugiarto \& Sitinjak (2001:96) menerangkan bahwa persepsi kualitas adalah persepsi 
pelanggan terhadap keseluruhan kualitas atau keunggulan suatu produk atau jasa layanan berkaitan dengan apa yang diharapkan oleh pelanggan. Sedangkan menurut Zeithaml dalam Killa (2008:417) menyebutkan persepsi kualitas sebagai penilaian subyektif konsumen tentang keunggulan atau kelebihan produk secara keseluruhan

Menurut Garvin dalam Aaker (1997: 134-136) dimensi persepsi kualitas produk terbagi menjadi tujuh, yaitu Kinerja (Performance), Fitur (Feature), Kesesuaian dengan Spesifikasi (Conformance with Specification), Keandalan (Reliability), Ketahanan (Durability), Pelayanan (Serviceability), dan Hasil Akhir (Fit and Finish),

Pengukuran variabel persepsi kualitas dalam penelitian menggunakan dimensi menurut Garvin dalam Aaker (1997: 134- 136) dan dikombinasikan dengan jurnalNurul (2012) yang disesuaikan dengan objek penelitian, dengan item pernyataan sebagai berikut :
1) Kinerja (Performance)
a. kapasitas mesin yang besar.
b. Kinerja mesin cukup baik
2) Fitur (Features)
a. Fitur eco driving
b. Kursi 3 baris
c. Fitur keamanan airbag
3) Keandalan (Reliability)
a. Dapat diandalkan dalam kondisi jalan menanjak
4) Ketahanan (Durability)
a. Mobil ini memiliki daya tahan yang lama.
5) Pelayanan (Serviceability)
a. Suku cadang Datsun Go Panca mudah di dapatkan
b. biaya pemeliharaan yang murah.

\section{Pengetahuan Produk dan Niat Beli}

Menurut Ujang Sumarwan (2008:147), Penting bagi pemasar untuk memahami pengetahuan konsumen, karena apa yang dibeli, berapa banyak yang dibeli, dimana membeli, dan kapan membeli akan tergantung kepada pengetahuan konsumen mengenai hal-hal tersebut. Maka, pengetahuan konsumen sangat mempengaruhi keputusan pembelian. Ketika konsumen memiliki pengetahuan yang lebih banyak, maka ia akan lebih baik dalam mengambil keputusan, ia akan lebih efisien daln lebih tepat dalam mengolah informasi dan mampu marecall informasi yang lebih baik.

Besarnya pengetahuan konsumen akan suatu produk sangat penting guna mendorong niat beli masyarakat untuk membeli produk tersebut. Sebagaimana dikemukakan NanHongLin dan Bih Shya Lin (2007) bahwa pengetahuan produk berperan penting dalam mempengaruhi niat konsumen dalam membeli sebuah produk.Penelitian dilakukan Kambiz Heidarzadeh dan Shirin (2011) menghasilkan bahwa pengetahuan produk yang tinggi mengenai spesifik produk, akan lebih condong untuk segera menggunakan produk tersebut. Penelitian Ratna Susanti dan Dwi Hastjarja .K (2010)

Dalam penelitian ini sampel yang dipilih adalah seseorang yang belum memiliki mobil Datsun Go Panca dan berusia 25 tahun ke atas.Jumlah sampel yang digunakan sebanyak 210 responden,dengan menggunakan metode nonprobability samplingdengan teknik pengambilan sampel menggunakan judgmental sampling.

Teknik pengumpulan data yang digunakan dalam penelitian ini adalah wawancara, dokumentsai dan juga menyebutkan bahwa pengetahuan produk dapat berpengaruh secara langsung terhadap niat pembelian. Dan juga penelitian yang dilakukan David Bamber, Suniti Phadke, Amalendu Jyotishi (2011) menunjukkan bahwa pemasar dapat menggunakan pengetahuan yang diperoleh sebagai dasar untuk masuk ke pasar guna memilih produk berdasarkan pengetahuannya.

H1 :Ada pengaruh pengetahuan produk terhadap niat beli Datsun Go.

\section{Persepsi Kualitas dan Niat Beli}

Besarnya niat konsumen untuk membeli suatu produk juga di pengaruhi oleh persepi kualitas produk di benak konusmen, seperti penelitian dari Asma .S(2012), bahwa persepsi produk berpengaruh signifikan terhadap niat beli, niat beli di pengaruhi seberapa baik persepsi produk yang di persepsikan oleh konsumen.

Persepsi konsumen akan suatu produk sangat penting guna mendorong niat beli masyarakat untuk membeli produk tersebut. Sebagaimana dikemukakan Nurul .I (2012) bahwa persepsi kualitas produk berperan penting dalam mempengaruhi niat konsumen dalam membeli sebuah produk.Penelitian yang dilakukan Rico .S (2013) menghasilkan bahwa persepsi kualitas produk yang tinggi, akan lebih condong untuk segera menggunakan produk tersebut. Penelitian Asma .S (2015) juga menyebutkan bahwa persepsi kualitas produk dapat berpengaruh secara langsung terhadap niat pembelian.

$\mathrm{H} 2$ :Ada pengaruh persepsi kualitas terhadap niat beli Datsun Go.

\section{METODE PENELITIAN}

Rancangan penelitian yang digunakan ada dengan metode konklusif untuk mengetahui apakah variabel bebas (variabel independen) yang berupa pengetahuan produk dan persepsi kkualitasakan berpengaruh terhadap variabel terikat (variabel dependen) yaitu niat beli pada produk mobil LCGC Datsun Go Panca di kota Surabaya.

Populasi dalam penelitian ini adalah pengunjung pameran penjualan mobil LCGC di Royal Plaza, Delta Plaza, dan tunjungan Plaza.Jumlah populasi dalam penelitian ini bersifat infinite atau tidak diketahui. Karakteristik populasi dalam penelitian ini adalah :

1. Responden adalah orang yang pernah membandingkan dan mengevaluasi semua merek mobil LCGC, dan telah mengunjungi pameran mobil LCGC Datsun Go Panca minimal 2 kali.

2. Responden sudah pernah berinteraksi langsung dengan sales penjualan Datsun.

3. Responden dalam penelitian ini yang berusia 25 tahun ke atas.

menyebarkan angket kepada responden.Skala pengukuran yang digunakan adalah skala likert. Skala likert adalah skala yang digunakan secara luas yang meminta responden menandai derajat persetujuan atau ketidaksetujuan terhadap masing-masing dari serangkaian pernyataan mengenai objek stimulus dalam pengukurannya setiap item skala mempunyai bobot 1 dengan "sangat tidak setuju" sampai dengan bobot 5 dengan "sangat setuju". 
Teknik analisis data menggunakan analisis regresi linear berganda. Setelah melalui uji validitas, diketahui bahwa semua item-item pernyataan dalam indikator untuk variabel pengetahuan produk, persepsi kualitas dan niat beli memiliki nilaicorrectedtem-total correlation lebih besar dari nilai $\mathrm{r}_{\text {tabel }}(0,30)$ sehinggadapat disimpulkan bahwa pernyataanpernyataan pada instrumenpenelitian (angket) dinyatakan valid dan dapat digunakan sebagai alat ukur untuk mengukur pengaruh pengetahuan produk dan persepsi kualitas terhadap niat beli.

Hal tersebut menunjukkan bahwa indikator dari masingmasing variabel dinyatakan valid atau dapat mengukur variabel-variabel tersebut dengan tepat. Setelah melalui uji reliabilitas, diketahui bahwa nilai Cronbach's Alpha untuk masing-masing variabel memiliki nilai lebih besar dari 0,70 sehingga dapat dinyatakan bahwa keseluruhan variabel memiliki reliabilitas yang baik.

\section{ANALISIS DATA}

Teknik analisis data yang digunakan dalam penelitian ini adalah model persamaan regresi linier berganda dengan menggunakan uji asumsi klasik yaitu uji normalitas, uji multikolinieritas dan uji heterokedastisitas. Hasil uji normalitas memperlihatkan bahwa nilai signifikan 0,862 lebih besar dari 0,05. Hal tersebut menunjukkan residual terdistribusi normal. Hasil uji multikolinieritas dapat diketahui dengan cara melihat hasil nilai tolerance dan VIF. Nilai tolerance variabel pengetahuan produkdan persepsi kualitas adalah 0,496 dimana nilai ini berada di atas 0,10 dan nilai VIF adalah 2,017 dimana nilai ini berada dibawah 10 sehingga dapat disimpulkan bahwa uji regresi tidak terdapat gejala multikolonieritas. Hasil uji heteroskedastisitas dengan menggunakan uji Glejser menunjukan bahwa nilai signifikasi variabel pengetahuan produk sebesar 0,466 dan persepsi kualitas sebesar 0,289 di mana lebih besar dari 0,05 sehingga dapat disimpulkan bahwa dalam model regresi tidak terjadi gejala hesteroskedastisitas.

Berdasarkan hasil deskripsi karakteristik demografi responden, dapat diketahui bahwa responden yang dijadikan obyek penelitian ini didominasi oleh responden yang berusia 36 - 46 tahun sebanyak 106 responden, dengan jenis kelamin laki - laki sebanyak 175 responden, dengan pekerjaan sebagai wirausaha sebanyak 84 responden dan memiliki penghasilan antara Rp. 4.000.000 - Rp. 5.000.000sebanyak 127 responden.

Tahap selanjutnya yaitu menguji model regresi linier berganda. Setelah dilakukan pengujian model regresi linier berganda maka dilakukan uji hipotesis yang terdiri dari uji t. Hasil regresi linier berganda dan uji t dapat dilihat pada tabel berikut

:Tabel 2. Coefficients

\begin{tabular}{|c|c|c|c|c|c|}
\hline \multirow[t]{2}{*}{ Model } & \multirow[t]{2}{*}{ B } & Std. & Beta & $\mathrm{T}$ & $\mathrm{Sig}$ \\
\hline & & \multicolumn{4}{|l|}{ Error } \\
\hline Constant & -1.314 & .715 & & -1.837 & .068 \\
\hline Persepsi Kualitas & 344 & .041 & .580 & 8.312 & .000 \\
\hline Pengetahuan Produk & k. 073 & .031 & .166 & 2.373 & .019 \\
\hline R Square & & .56 & & & \\
\hline
\end{tabular}

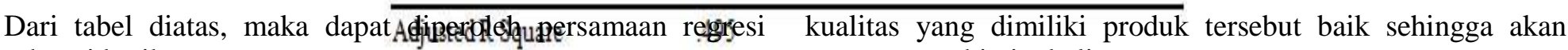
sebagai berikut:

$$
\begin{aligned}
& Y=-1,314+0,344 X_{1}+0,073 X \text { Sumber : data diolahpeneliti } \\
& \text { Keterangan : } \\
& \mathrm{Y}=\text { Niat Beli } \\
& \mathrm{X}_{1} \quad=\text { Pengetahuan Produk } \\
& \mathrm{X}_{2} \quad=\text { Persepsi Kualitas }
\end{aligned}
$$

Berdasarkan persamaan regresi berganda tersebut dapat diketahui bahwa:

a. Nilai Konstanta $(\alpha)$ sebesar -1,314 dapat diartikan bahwa apabila tidak ada variabel pengetahuan produk dan persepsi kualitas maka besarnya niat beli mobil Datsun Go Panca akan turun sebesar -1,314.

b. Koefisien Regresi untuk variable Pengetahuan produk $\left(\mathrm{X}_{1}\right)$ mempunyai pengaruh positif terhadap niat beli mobil Datsun Go Panca sebesar 0,344.

c. Koefisien Regresi untuk variabel Persepsi kualitas $\left(\mathrm{X}_{2}\right)$ mempunyai pengaruh positif terhadap niat beli mobil Datsun Go Panca sebesar 0,073.

Dari persamaan regresi tersebut menunjukkan bahwa seseorang hendak membeli sebuah mobil pasti memiliki pengetahuan tentang produk yang akan dipilih dan persepsi

mempengaruhi niat beli seseorang.

Berdasarkan tabel ditas dapat diketahui bahwa nilai signifikansi pada variabel pengetahuan produk dan persepsi kualitas lebih kecil daripada nilai alpha $(0,05)$ sehingga hipotesis diterima dengan kesimpulan bahwapengetahuan produk dan persepsi kualitas akan mempengaruhi niat beli mobil Datsun Go Panca. Selain itu hasil dari Adjusted $R$ Square menunjukkan bahwa pengetahuan produk dan persepsi kualitas mempengaruhi niat beli sebesar 0,495 atau 49,5\% dan sisanya dipengaruhi oleh variabel lain seperti harga dan citra merek. Sehingga dapat disimpulkan bahwa secara simultan pengetahuan produk dan persepsi kualitas mempengaruhi niat beli.

Hasilujitpadapenelitian iniberdasarkantabelCoefficients diatas dapat ditarik kesimpulan sebagai berikut:

a. Nilai $t_{\text {hitung }} \mathrm{X}_{1}$ sebesar 8,312didukung dengan nilai sign. sebesar 0,00 yang lebih kecil 0,05 maka Ho ditolak dan Ha diterima, sehingga dapat dikatakan variabel pengetahuan produk $\left(\mathrm{X}_{1}\right)$ mempunyai pengaruh signifikasi terhadap niat beli $(\mathrm{Y})$.

b. Nilai $t_{\text {hitung }} \mathrm{X}_{2}$ sebesar 2,373didukung dengan nilai sign. sebesar 0,19 yang lebih kecil 0,05 maka Ho ditolak dan $\mathrm{Ha}$ diterima, sehingga dapat dikatakan variabel 
persepsi kualitas $\left(\mathrm{X}_{2}\right)$ mempunyai pengaruh signifikasi terhadap niat beli (Y).

c. Berdasarkan perbandingan nilai $\mathrm{t}_{\text {hitung }}$ dari tiap variabel bebas, maka dapat diketahui bahwa variabel pengetahuan produk $\left(\mathrm{X}_{1}\right)$ memiliki pengaruh yang dominan dengan nilai $t_{\text {hitung }}$ sebesar 8,312 lebih besar daripada $t_{\text {hitung }}$ variabel persepsi kualitas $\left(\mathrm{X}_{2}\right)$ sebesar 2,373.

\section{HASIL DAN PEMBAHASAN}

\section{Pengaruh Pengetahuan Produk terhadap Niat Beli}

Variabel pengetahuan produk menunjukan adanya hubungan positif terhadap niat beli, karena semakin banyaknya pengetahuan produk yang diberikan oleh perusahaan membuat konsumen dapat memiliki banyak pengetahuan akan produk tersebut, maka dapat mendorong konsumen untuk memunculkan niat beli terhadap produk Datsun Go Panca atau diuntungkan oleh produk Datsun Go Panca.

Hal tersebut didukung Mountinho (2011) menyatakan bahwa, ketika konsumen memilih produk, mereka biasanya mengandalkan pengetahuan produk mereka untuk mengevaluasi itu, dan pengetahuanp roduk merekaakan mempengaruhi proses pencarian informasi mereka, dan kuantitas pencarian informasi.didukung oleh teori yang dikemukakan oleh Sumarwan (2011:169) keingintahuan adalah salah satu karakter konsumen yang penting. Ia selalu ingin tahu banyak hal, merupakan kebutuhan konsumen. Sering kali konsumen perlu tahu produk terlebih dahulu sebelum ia menyukai kemudian membeli produk tersebut. Pengetahuan yang baik mengenai suatu produk sering kali mendorong seseorang untuk menyukai produk tersebut, Datsun telah lama hadir di Indonesia, dan memiliki image yang cukup baik di mata konsumen, seteleh beberapa tahun terhentinya produksi Datsun di Indonesia, Datsun kembali hadir dengan konsep LCGC.

Dalam penelitian ini variabel pengetahuan produk diukur dengan menggunakan dua indikator yaitu pengetahuan objektif dan pengetahuan subjektif.Berdasarkan hasil dari jawaban responden melalui pernyataan-pernyataan dalam mengukur pengetahuan produk, menunjukan bahwa untuk memunculkan niat beli terhadap produk, dipengaruhi oleh seberapa banyak pengetahuan yang tersimpan dalam memori dan dimiliki oleh konsumen pada produk Datsun Go Panca. Hal tersebut terkait akan pengetahuan produk tentang fiturfitur yang dimiliki produk tersebut. disesuaikan dari penelitian Dwi Hastjarja .K (2010), yang menyatakan bahwa niat beli konsumen di pengaruhi oleh seberapa banyak pengetahuan yang di miliki tentang produk yang akan di beli.

Dalam memunculkan niat beli dan merasakan keuntungan terhadap suatu produk juga di nilai dari pengetahuan subjektif, hal ini sesuai seperti penelitian oleh Penelitian Bih Shya Lin (2007) yang menggunakan pengetahuan objektif dan subjekif.pengetahuan subjektif yang dimiliki konsumen yang juga merupakan presepsi konsumen tentang seberapa banyak pengetahuan yang dimilikinya tentang produk tersebut. Hal ini juga didukung oleh hasil dari jawaban responden melalui pernyataan dalam pengukuran pengetahuan subjektif responden setuju bahwa pernyataan dalam pengukuran pengetahuan subjektif dapat mempengaruhi konsumen dalam menentukan niat beli terhadap produk Datsun Go Panca.

Berdasarkan beberapa indikator dalam mengukur pengetahuan produk terhadap niat beli Datsun Go Panca, indikator yang memiliki pengaruh lebih besar adalah pengetahuan objektif. Dengan pernyataan "saya mampu mengingat segala sesuatu tentang atribut produk Datsun Go di banding dengan mobil LCGC lainnya", Sedangkan yang memiliki nilai rata-rata terendah adalah dimensi pengetahuan subjektif dengan pernyataan "saya banyak mengetahui tentang produk mobil Datsun Go" sehingga dapat disimpulan untuk memunculkan niat beli terhadap produk Datsun Go Panca bisa didapatkan ketika konsumen telah mampu mengingat atribut produk Datsun Go di bandingkan dengan produk LCGC lainnya. Namun banyaknya pengetahuan tentang produk Datsun, tetap harus di imbangi dengan kemampuan konsumen dalam mengingat atirbut produk Datsun Go dibandingkan dengan produk LCGC lainnya.

Disesuaikan dengan hasil karakteristik responden dimana responden dalam penelitian adalah wirausaha dan pegawai swasta dengan usia antara 36-46 tahun, dimana pada usia tersebut konsumen akan jauh lebih menilai seberapa banyak pengetahuan yang telah dimiliki tentang produk Datsun Go Panca agar dapat memunculkan niat beli produk tersebut. Selain itu, pada usia tersebut konsumen akan jauh lebih selektif dalam memilih produk terutama terkait akan produk transportasi yang berhubungan dengan kemanan, kenyamanan dalam menggunakan produk transportasi.

\section{Pengaruh Persepsi Kualitas terhadap Niat Beli}

Variabel Persepsi kualitas pada penelitian ini berpengaruh secara signifikan terhadap niat beli Datsun Go Panca karena konsumen yang memiliki persepsi positif terhadap suatu produk akan cenderung memeliki niat beli terhadap produk tersebut. Variabel persepsikualitas pada penelitian ini berpengaruh secara signifikan menjadikan persepsi kualitas sebagai variabel yang memberi pengaruh terhadap niat beli Datsun Go Panca.

Hasil penelitian ini sesuai dengan teori Zeithaml dalam Killa (2008:417) menyebutkan persepsi kualitas sebagai penilaian subyektif konsumen tentang keunggulan atau kelebihan produk secara keseluruhan. Dengan demikian, dapat disimpulkan bahwa persepsi kualitas adalah persepsi atau penilaian pelanggan terkait dengan keunggulan suatu produk atau jasa secara keseluruhan. Berdasarkan pendapat para ahli, dapat disimpulkan bahwa persepsi adalah suatu proses dengan mana berbagai stimuli dipilih, diorganisir, dan diinterpretasi menjadi informasi yang bermakna.

Penelitian ini didukung oleh penelitian yang dilakukan Rico S (2013) yang menyatakan perspesi kualitas yang baik pada konsumen tentang suatu produk akan meningkatkan niat beli konsumen.

Dalam penelitian ini variabel persepsi kualitas diukur dengan menggunakan delapan dimensi, yaitu kinerja, fitur, keandalan, ketahanan, dan pelayanan.item pernyataan yang memiliki nilai rata-rata tertinggi adalah pernyataan "Saya percaya mobil Datsun Go Panca memiliki kapasitas mesin besar yang lebih membuat responsif saat berekendara".. Sehinggal Indikator kinerjapada variabel persepsi kualitas memiliki rata-rata yang tertinggi dibandingkan dengan indikator yang lainnya. 
Indikator kinerja merupakan indikator yang dominan dalam mempengaruhi niat beli, hal ini disebabkan mobil DatsunGo Panca dari segi mesin pabrikan Nissan memiliki kapasitas mesin yang besar sehingga kinerja mesin tersebut sangat baik.

Sedangkan item pernyataan yang memiliki nilai rata-rata terendah pada dimensi pelayanan dengan pernyataan "Biaya service mobil Datsun Go Panca yang relatif murah bagi saya", dapat disimpulkan sebelum, berniat membeli mobil Datsun Go Panca, selain biaya perawatan yang murah, konsumen lebih fokus pada kinerja mesin mobil tersebut.

Disesuaikan dengan hasil penelitian dari Husin (2015) yang menyatakan bahwa persepsi kualitas yang dirasakan konsumen akan mempengaruh seberapa besar niat beli konsumen tersebut dengan beberapa dimensi seperti kinerja dan pealayan.

Dari dua variabel pengetahuan produk dan perepsi kualitas, variabel yang memiliki pengaruh tertinggi adalah pengetahuan produk yang dimiliki oleh konsumen dengan nilai rata-rata sebesar $3,76 \%$. Item pernyataan yang memiliki nilai tertinggi adalah "saya mampu mengingat segala sesuatu tentang atribut produk Datsun Go Panca dibanding dengan mobil LCGC lainnya". Hal ini menunjukan bahwa pengetahuan konsumen akan suatu produk khususnya produk LCGC Datsun, berpengaruh terhadap niat beli konsumen.

\section{KESIMPULAN}

Berdasarkan hasil analisis data dan pembahasan hasil penelitian yang dilakukan oleh peneliti, terdapat pengaruh pengetahuan produk terhadap niat beli mobil Datsun Go Panca dan terdapat pengaruh persepsi kualitas terhadap niat beli Datsun Go Panca.

Disarankan untuk melakukan penelitian di luar variabel bebas (pengetahuan produk dan persepsi kualitas) yang digunakan dalam penelitian ini, diantaranya harga dan citra merek. Dalam penelitian ini diketahui variabel persepsi kualitas sebagai variabel yang memiliki pengaruh paling kecil terhadap niat beli datsun Go Panca. Hal ini menunjukkan bahwa persepsi kualitas yang dirasakan konsumen tidak cukup untuk mempengarhui niat beli dan harus di imbangi pengetahuan produk yang baik . Jadi untuk tetap mempertahankan penjualannya, Datsun lebih baik memberikan informasi melalui berbagai media agar konsumen memiliki banyak pengetahuan tentang mobil LCGC khususnya Datsun Go Panca. Berdasarkan hasil pernyataan per-indikator, pernyataan $\left(\mathrm{X}_{2.5 .2}\right)$ yang memiliki mean atau nilai rata-rata terendahdengan pernyataan "biaya service yang relaitf murah bagi saya" sehingga disarankan perusahaan Datsun memberikan beberapa potongan harga ketika konsumen melakukan service kendaraan, atau memberikan free jasa service selema waktu yang sudah ditentukan agar konsumen dapat merasakan pelayanan yang baik saat melakukan service kendaraanya.

Toyota Agya di Kota Denpasar.Skripsi tidak diterbitkan Bali: FE: UNUD

Nurul Istiqomah 2012, "persepsi kualitas terhadap niat beli pada sepeda motor yamaha mio". Jurnal.Vol 33 No.4.Universitas Islam Negeri Sunan kalijaga yogyalkarta

\section{REFERENSI}

Aaker, David. (1997). Manajemen Ekuitas Merek. Jakarta:Spektrum.

Asma Saleem and Naveed Ahmed 2015. Product Perceived Quality And Purchase Intention With Customer Statisfaction.10, No.1,(2015)1-15

David Bamber.,et al.2011. Product-Knowledge, Ethnocentrism and Purchase Intention: COO Study in India. MBAbookjournal. Working Paper No.112/2011

DuriantoD., Sugiarto dan Sitinjak, T. 2001.StrategiMenaklukan Pasar Melalui Riset Ekuitas dan Perilaku Merek. Jakarta: PT Gramedia Pustaka Utama

Engel, J.F., Blackell, R.D., \& Miniard, P.W.1993. PerilakuKonsumen.Edisi 6 Jilid 1.Terjemahan oleh Budjianto.1995. Jakarta: Binarupa Aksara

Fandy Tjiptono, 2005. Pemasaran Jasa, Malang: Bayumedia Publishing.

KambizHeidarzadeh Hanzaee and Shirin Khosrozadeh. 2011. The Effect of the Country-of-Origin Image, Product Knowledge and Product Involvement on Information Search and Purchase Intention. Middle-East Journal of Scientific Research 8 (3): 625-636

Killa, Maklon. 2008. Jurnal Ekonomi dan Bisnis Indonesia,Volume 23 No. 4. Yogyakarta: Bagian penerbitanFakultas Ekonomi Universitas Gadjah Mada

Kotler, Philip dan Amstrong Gary. 2008. PrinsipPrinsipPemasaran. Edisi 12.Bahasa Indonesia Jilid 1.Jakarta :Erlangga.

Kotler,Philip. 2009.Manajemen Pemasaran. Jakarta :Erlangga

Kotler,Phillip\&Armstrong (2006) "MarketingManagement" Twelfth Edition,Pearson

Kotler, Phillip.2001.ManajemenPemasarandiIndonesia EdisiBahasaIndonesia.Jakarta:PTSalemba Empat.

Larkin,P.J.andW.R.Scowcroft.1981.Somaclonalvariation-a novel source of variability from cellcultureforplantimprovementTheor.Appl. Gen.60:197214.

Leow Chee Seng, 2015. Product perceived Quality and Price Influnence on Cars Purchase Intention in Malaysia.

Lin, L., dan Zhen, J. 2005. Extrinsic Product Performance

Signaling,ProductKnowledgeandCustomer Satisfaction: an Integrated Analysis Fun Jen Management Review 12 (1), 65-91.

Nan-Hong Lin dan Bih-Syah Lin. 2007.The effect of Brand Image and Product Knowledge on Purchase Intention Moderated By Price Discount. Journal of International Management Studies * August 2007

Ni Putu Novia Mandasari, Roselina dan Nurcaya, I Nyoman. 2012. Pengaruh Sikap Konsumen dan Norma Subyektif terhadap Niat Beli

Peter J. Paul dan Olson Jerry C. (2010).Consumer Behavior and marketing Strategy 9 New York, USA : Mc Grawhill.

Rodoula Tsiotsou, 2005. The Role of Perceived Quality and Overall Satisfaction on Purchase Intention.Marketing

Bulletin, 2005, 16, Research Note 4. 
BISMA - Bisnis dan Manajemen -Volume 9 No. 1 Oktober 2016

Roselina Ni Putu Novia Mandasari dan I Nyoman Nurcahya .2012. Pengaruh Sikap Konsumen dan Norma Subyektif Terhadap Niat Beli Mobil Toyota Agya di Kota Denpasar. Bali: Universitas Udayana Bali. 99.

Roslina.2009. Pengaruh Pengetahuan Produk dan Citra Merek Terhadap Pembelian Produk.Jurnal Manajemen dan Bisnis. Vol 10,No 2.2009. ISSN: 1412 - 3681.
Saputra Rico, 2013. Pengaruh Motivasi, Persepsi Kulitas, dan sikap konsumen Terhadap Niat beli Mobil Daihatsu Xenia. Jurnal Manajemen Pemasaran Vol. 1, No. 1, (2013) 1-12.

Schiffman, L.G dan Kanuk, Lesley L. 2010.Consumer Behavior tenth Edition.Person Education.

Sugiyono (2009).Metode Penelitian Bisnis (Pendekatan Kuantitatif, Kualitatif, dan R\&D). Bandung: Alfabeta 